\title{
VERIFIKASI METODE PENENTUAN ASETOSAL DALAM OBAT SAKIT KEPALA DENGAN METODE SPEKTROFOTOMETRI UV
}

\author{
Kuntari $^{1}$, T. Aprianto2, R. Hadiyati Noor ${ }^{3}$, Baruji ${ }^{4}$ \\ DIII Analis Kimia, Fakultas Matematika dan IImu Pengetahuan Alam \\ Universitas Islam Indonesia \\ Yogyakarta, Indonesia
}

e-mail: 1'chemist.tari@gmail.com,162310401@uii.ac.id

\begin{abstract}
Abstrak
Asetosal merupakan suatu obat yang berfungsi sebagai analgesik, antipiretik dan antiinflamasi yang sering digunakan oleh masyarakat luas. Penggunaan asetosal dalam dosis tinggi dapat menyebabkan indikasi dan efek negatif bagi tubuh sehingga pengawasan mutu yang menyangkut kandungan asetosal pada produk obat sangat penting. Metode penetapan kadar asetosal yang dikembangkan harus memenuhi parameter validitas suatu metode analisis dan terverifikasi. Metode penetapan kadar asetosal yang digunakan dalam penelitian ini adalah metode spektrofotometri UV. Metode spektrofotometri UV merupakan metode yang memiliki tingkat kesulitan yang rendah, cepat, selektif, sensitif dan murah. Berdasarkan hasil uji parameter validasi, nilai LoD (Limit of Detection), LoQ (Limit of Quantification), presisi, akurasi dan estimasi ketidakpastian pengukuran termasuk dalam kategori baik, dengan nilai secara berurutan adalah 0,9967; 0,0664 mg/L;2,2131 mg/L, 3,7856 \%; 93,88\% dan \pm $0,3163 \mathrm{~g} / \mathrm{mL}$.
\end{abstract}

Kata kunci: asetosal, spektrofotometri, UV, verifikasi

\begin{abstract}
Acetosal is a drug that works as an analgesic, antipyretic and anti-inflammatory that is often used by the public. The use of acetocal in high doses can cause indication and negative effects to the body so that the quality control concerning the content of acetosal on medicinal products is important. Determination methods of acetosal which developed must appropriateto the validity parameters of a analysis method and verified. Determination method of acetosal which used in this research is UV spectrophotometric method. UV-spectrophotometric method is a method that has a low level of difficulty, rapid, selective, sensitive and inexpensive. Based on the test results of the validation parameter,value of LoD (Limit of Detection), LoQ (Limit of Quantification), precision, accuracy and uncertainty estimation are included in the good category, the value is $0.9967 ; 0.0664 \mathrm{mg} / \mathrm{L} ; 2.2131 \mathrm{mg} / \mathrm{L}, 3.7856 \% ; 93.88 \%$ and \pm $0.3163 \mathrm{~g} / \mathrm{mL}$, respectively.
\end{abstract}

Keywords: acetosal, spectrophotometry, UV, verification

\section{PENDAHULUAN}

Asetosal atau asam asetil salisilat merupakan jenis obat turunan salisilat. Nama sistematis IUPAC (International Union of Pure and Applied Chemistry) asetosal adalah asam 2-asetilbenzoat asam asetat. Struktur kimia senyawa asetosal ditunjukkan pada Gambar 1. Asetosal memiliki rumus molekul $\mathrm{C}_{9} \mathrm{H}_{8} \mathrm{O}_{4}$ dengan berat molekul $180,16 \mathrm{~g} / \mathrm{mol}$, kelarutan dalam air $3 \mathrm{mg} / \mathrm{mL}$ 
$\left(20^{\circ} \mathrm{C}\right)$ titik leleh $135^{\circ} \mathrm{C}$ merupakan kristal dengan pemerian serbuk berwarna putih, tidak memiliki bau yang kuat.

Asetosal yang sering dikenal sebagai aspirin digunakan oleh masyarakat luas sebagai analgesik atau penahan rasa sakit atau nyeri minor, antipiterik (penurun demam) dan anti-inflamasi (peradangan). Penggunaan aspirin dalam dosis yang terlalu tinggi dapat menyebabkan beberapa indikasi dan dampak negatif seperti iritasi lambung, perdarahan, perforasi atau kebocoran lambung serta menghambat aktivitas trombosit. Penentuan kadar asetosal dalam sediaan obat menjadi sangat penting untuk uji kualitas produk sebelum dan selama proses produksi maupun setelah menjadi produk akhir.<smiles>CC(=O)Oc1ccccc1C(=O)O</smiles>

Gambar 1. Struktur molekul asetosal

Pengawasan mutu yang menyangkut kandungan asetosal pada produk obat harus ditingkatkan dengan mengembangkan metode penetapan kadar yang dapat memenuhi parameter validitas suatu metode analisis. Di samping hal tersebut penting mengembangkan metode yang memiliki tingkat kesulitan yang rendah, cepat, dan membutuhkan biaya yang lebih sedikit.

Beragam metode analisis kuantitatif telah banyak dikembangkan untuk penetapan kadar asetosal dan metabolitnya dalam sediaan obat. Penentuan asetosal dalam sampel obat dengan metode spektrofotometri dan kromatografi (Bharate dan Bharate, 2012);spektrofotometri UV (Mishra dan Archana, 2006), (Gujarathi, 2010) dan (Murtaza dkk., 2011);kromatografi cair (Martos dkk., 2001); spektrofluorometri (Martos dkk., 2001); kromatografi cair kinerja tinggi (Cemal dkk, 2008) dan spektrofotometri raman (Szostak \& Mazurek, 2002). Metode spektrofotometri UV dinilai sebagai metode yang memiliki tingkat kesulitan rendah, cepat, selektif, sensitif dan murah. Oleh karena itu dalam penelitian ini dilakukan verifikasi metode penentuan asetosal dalam sediaan obat, dalam hal ini obat sakit kepala dengan metode spektrofotometri UV.

Tujuan dari penelitian ini adalah memperoleh validitas metode analisis untuk penentuan kadar asetosal dalam obat sakit kepala secara spektrofotometri uv dengan parameter uji meliputi linearitas, presisi, akurasi, $L o D, L O Q$ dan nilai ketidakpastian pengukuran. Hasil yang diharapkan adalah tersedianya data evaluasi kinerja metode spektrofotometri UV dalam penentuan kadar asetosal dalam obat sakit kepala, menjamin linearitas, akurasi, presisi, $L O D$ dan $L O Q$ dari hasil prosedur analisis dan mengurangi resiko penyimpangan.

\section{METODE \\ Alat dan Bahan}

Peralatan yang digunakan dalam penelitian ini meliputi neraca analitik merek OHAUS, pipet volume 1 dan $10 \mathrm{~mL}$; labu ukur 10, 50, 100 dan $250 \mathrm{~mL}$; gelas arloji, spatula, pipet tetes, gelas beker 100 dan 250 $\mathrm{mL}$, pengaduk gelas, pengaduk magnet dan spektrofotometer UV-Vis double beam HITACHI UH5300. Sementara bahan yang digunakan meliputi aspirin murni $(99,91 \%)$, $\mathrm{HCl}$ pekat $(37 \%)$, metanol p.a. produksi Merck, akuades dari Laboratorium Kimia Terapan, kertas whatmann 42, kertas seka dan tisu.

\section{Pembuatan larutan induk asetosal 100 $\mu \mathrm{g} / \mathrm{mL}$}

Sebanyak $10 \mathrm{mg}$ asetosal ditimbang dengan teliti kemudian ditambahkan larutan $\mathrm{HCl} 0,1 \mathrm{~N}$ : metanol (1:1) sebanyak $50 \mathrm{~mL}$ dalam gelas beker. Asetosal dan pelarut kemudian diaduk dengan pengaduk magnet hingga larut sempurna. Larutan yang dihasilkan setelah itu dimasukkan dalam labu ukur $100 \mathrm{~mL}$ dan ditambah $\mathrm{HCl} 0,1 \mathrm{~N}$ : metanol (1:1) sampai tanda batas. Larutan digojog hingga homogen, sehingga 
diperoleh larutan induk asetosal dengan konsentrasi $100 \mathrm{mg} / \mathrm{L}$.

\section{Pembuatan larutan standar asetosal}

Larutan standar asetosal dibuat dengan variasi konsentrasi $0,2,4,6,8$ dan $10 \mathrm{mg} / \mathrm{L}$ yaitu dengan memipet larutan induk asetosal $100 \mathrm{mg} / \mathrm{L}$ secara berurutan sebanyak 0,$2 ; 0,4 ; 0,6 ; 0,8$ dan $1 \mathrm{~mL}$. Masing-masing larutan induk asetosal hasil pemipetan dimasukkan ke dalam labu ukur $10 \mathrm{~mL}$ dan ditera sampai tanda batas dengan menggunakan pelarut $\mathrm{HCl} 0,1 \mathrm{~N}$ : metanol (1:1). Bagian atas labu diseka, kemudian dilakukan penggojogan sampaii homogen.

\section{Preparasi sampel}

Sejumlah $50 \mathrm{mg}$ sampel obat sakit kepala dimasukkan dalam gelas beker ukuran $100 \mathrm{~mL}$. Selanjutnya ditambah pelarut $\mathrm{HCl} 0,1 \mathrm{~N}$ : metanol (1:1) sebanyak $50 \mathrm{~mL}$ dan diaduk menggunakan pengaduk magnet hingga larut sempurna. Larutan dimasukkan dalam labu ukur $50 \mathrm{~mL}$ dan ditera dengan pelarut $\mathrm{HCl} 0,1 \mathrm{~N}$ : metanol (1:1) sampai batas. Bagian atas labu ukur diseka, kemudian dilakukan penggojogan hingga homogen. Tahap selanjutnya adalah penyaringan dengan kertas saring whatman 42. Filtrat yang diperoleh diambil sebanyak 1 $\mathrm{mL}$ dan dimasukkan dalam labu ukur $10 \mathrm{~mL}$. Kemudian, ke dalam labu ukur tersebut ditambah pelarut $\mathrm{HCl} 0,1 \mathrm{~N}$ : metanol (1:1) sampai tanda batas. Ujung labu ukur diseka, dilanjutkan dengan penggojogkan hingga homogen.

\section{Verifikasi metode analisis}

Tahap verifikasi metode meliputi penentuan panjang gelombang optimum, linearitas, $L o D, L o Q$, presisi dan akurasi. Penentuan panjang gelombang optimum dilakukan dengan mengukur absorbansi larutan standar dengan konsentrasi $6 \mathrm{mg} / \mathrm{L}$ pada panjang gelombang 200-400 nm dengan interval pengukuran $2 \mathrm{~nm}$. Penentuan linieritas dilakukan dengan melakukan pengukuran absorbansi deret kurva standar pada panjang gelombang optimum asetosal yang diperoleh. Kemudian dibuat kurva kalibrasi dengan sumbu $x$ adalah variasi konsentrasi larutan standar yaitu $0,2,4,6,8$ dan $10 \mathrm{mg} / \mathrm{L}$ serta sumbu y adalah respon absorbansi sampel pada variasi konsentrasi. Pembuatan kurva kalibrasi dilakukan duplo. Penentuan presisi dilakukan dengan mengukur absorbansi sampel pada panjang gelombang optimum sebanyak lima kali pengulangan. Larutan sampel yang akan diukur absorbansinya diencerkan terlebih dahulu. Faktor pengenceran sebesar lima puluh kali. Penentuan akurasi dilakukan dengan mengukur absorbansi standar asetosal 6 $\mathrm{mg} / \mathrm{L}$ pada panjang gelombang optimum dengan enam kali pengulangan. Penentuan konsentrasi $(x)$ untuk setiap pengukuran diperoleh dengan cara menghitung nilai $x$ yang diperoleh pada persamaan regresi linear kurva standar yang diperoleh, di mana y adalah nilai absorbansi larutan.

\section{HASIL DAN PEMBAHASAN \\ Penentuan Panjang Gelombang Optimum Asetosal}

Penentuan panjang gelombang optimum sangat berpengaruh dalam analisis kuantitafif menggunakan spektrofotometer karena perubahan konsentrasi yang kecil dapat menyebabkan perubahan absorbansi yang besar. Hasil pengukuran absorbansi larutan standar asetosal $6 \mathrm{mg} / \mathrm{L}$ disajikan pada Gambar 2. Berdasarkan Gambar 2 panjang gelombang optimum asetosal sebesar $237 \mathrm{~nm}$. Hasil penelitian ini tidak berbeda jauh dengan hasil yang diperoleh (Gujarathi, 2010) yang menyatakan bahwa panjang gelombang maksimum asetosal $232,98 \mathrm{~nm}$.

Selain puncak optimum untuk asetosal ternyata muncul puncak dari dianion salisilat yaitu pada panjang gelombang $304 \mathrm{~nm}$. Hasil tersebut memberikan informasi bahwa terjadinya hidrolisis asetosal menjadi dianion salisilat. Hidrolisis tersebut dapat terjadi karena standar asetosal yang digunakan, mengalami hidrolisis parsial akibat kelembaban yang berlangsung selama proses penyimpanan. 


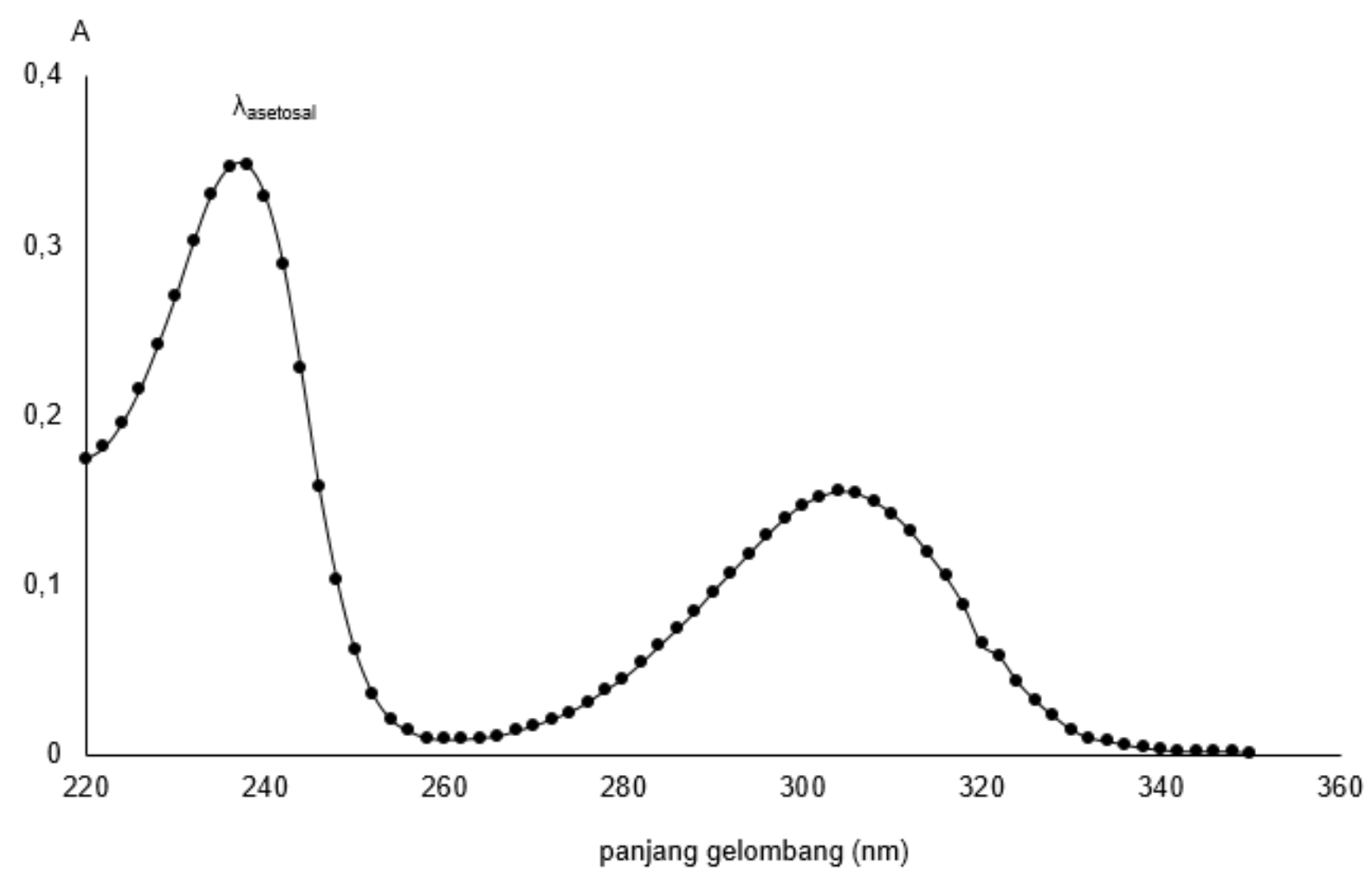

Gambar 2. Penentuan panjang gelombang optimum asetosal

Adanya serapan pada panjang gelombang tersebut akan memberikan pengaruh pada absorbansi sampel yang diukur. Absorbansi sampel pada panjang gelombang $237 \mathrm{~nm}$ akan berkurang, dengan kata lain hasil kadar asetosal terukur akan lebih kecil dari nilai yang sebenarnya. Hal ini dapat diminimalkan penyimpanan standar asetosal dalam kondisi tertutup bebas dari pengaruh kelembaban sekitar.

\section{Penentuan Linieritas}

Linearitas suatu metode terjadi ketika adanya hubungan berbanding lurus antara konsentrasi analit dengan respon metode selama dalam jangkauan kerja. Linearitas menunjukkan ketelitian metode analisis ketika harga $\mathrm{R}^{2}$ lebih besar dari 0,997 (Chan dkk., 2004).
Penentuan linearitas dalam penelitian dilakukan dengan membuat variasi konsentrasi larutan standar dari 2-10 mg/L. Berdasarkan hasil penelitian harga $R^{2}$ yang diperoleh yaitu sebesar 0,9967. Hasil tersebut mengindikasikan bahwa metode memiliki tingkat linearitas yang baik pada jangkauan kerja atau range konsentrasi 2-10 $\mathrm{mg} / \mathrm{L}$.Data penentuan linearitas ditampilkan pada Tabel 1. Berdasarkan Tabel 1 dibuat kurva kalibrasi yang ditunjukkan pada Gambar 3. Persamaan regresi linear yang diperoleh tahap ini yang digunakan untuk penentuan kadar asetosal tahap-tahap berikutnya. Harga slope yang diperoleh berdasarkan persamaan regresi linear yang diperoleh yaitu sebesar 0,0599 dan intersep sebesar 0,0116. 
Tabel 1. Data pengukuran larutan standar asetosal dengan spektrofotometer UV

\begin{tabular}{ccccc}
\hline $\begin{array}{c}\text { Konsentrasi } \\
(\mathrm{mg} / \mathrm{L})\end{array}$ & $\begin{array}{c}\text { Absorbansi } \\
\text { Replikat 1 }\end{array}$ & $\begin{array}{c}\text { Absorbansi } \\
\text { Replikat 2 }\end{array}$ & $\begin{array}{c}\text { Absorbansi } \\
\text { Rata-rata }\end{array}$ & $\begin{array}{c}\text { Standar Deviasi } \\
\text { (STD) }\end{array}$ \\
\hline 0 & 0,0000 & 0,0000 & 0,0000 & 0,0000 \\
2 & 0,1373 & 0,1238 & 0,1306 & 0,0095 \\
4 & 0,2769 & 0,2612 & 0,2691 & 0,0111 \\
6 & 0,3699 & 0,3693 & 0,3696 & 0,0005 \\
8 & 0,5021 & 0,5044 & 0,5032 & 0,0016 \\
10 & 0,5741 & 0,6169 & 0,5956 & 0,0303 \\
& & & & \\
\end{tabular}

Nilai slope (gradien) yang diperoleh dari perhitungan mencerminkan sensitivitas dari metode. Semakin sensitif suatu metode analisis maka nilai koefisien relasi semakin mendekati satu karena sensitivitas menunjukkan rasio antara perubahan respon alat ukur terhadap perubahan konsentrasi analit yang diukur yang ditentukan oleh kemiringan atau slope grafik kalibrasi.

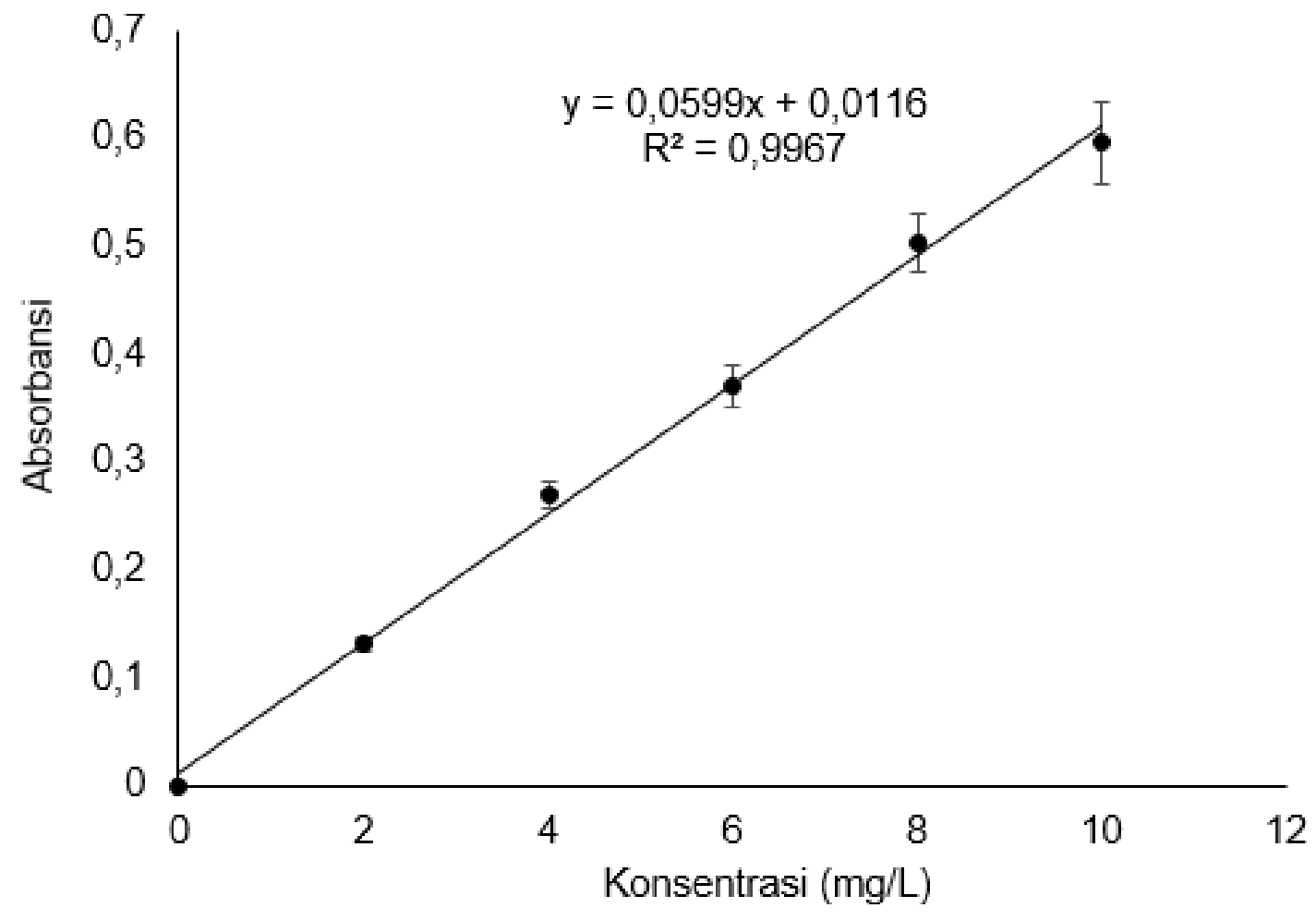

Gambar 3. Kurva kalibrasi larutan standar asetosal

\section{Penentuan $L O D$ dan $L O Q$}

Limit deteksi adalah jumlah terkecil analit dalam contoh yang dapat dideteksi yang masih memberikan respon signifikan dibandingkan dengan blanko dan berada pada kondisi yang disepakati, sedangkan limit kuantitasi adalah konsentrasi terendah analit dalam sampel yang dapat ditentukan dengan presisi dan akurasi yang dapat diterima dibawah kondisi yang disepakati (Kantasubrata, 2008). Penentuan nilai LoD dan $L O Q$ pada suatu metode analisis dapat dilakukan menggunakan dua cara yaitu penentuan blanko dan kurva kalibrasi. Penentuan blanko diterapkan ketika analisis blanko memberikan hasil standar deviasi tidak nol. LoD dinyatakan sebagai konsentrasi analit yang sesuai dengan nilai 
blanko sampel ditambah tiga standar deviasi dan $L O Q$ adalah konsentrasi analit yang sesuai dengan nilai blanko sampel ditambah sepuluh standar deviasi seperti yang ditunjukkan dalam persamaan (1) dan (2).

$$
\begin{aligned}
& L o D=x+3 S b \\
& L o Q=x+10 S b
\end{aligned}
$$

$\mathrm{x}$ adalah konsentrasi rata-rata blanko dan $\mathrm{Sb}$ adalah standar deviasi dari blanko. Sementara penentuan $L O D$ dan $L o Q$ secara kurva kalibrasi linear diasumsikan bahwa respon instrumen $(y)$ berhubungan secara linier dengan konsentrasi standar $(\mathrm{x})$ untuk rentang yang terbatas konsentrasi. Hal ini dapat dinyatakan dalam model persamaan $y=b x+a$. Model ini digunakan untuk menghitung sensitivitas (b) dan $L O D$ dan $L o Q$ (6). Oleh karena itu $L o D$ dan $L o Q$ dapat dinyatakan pada persamaan (3) dan (4).

$$
\begin{aligned}
& L O D=\frac{\mathrm{S}_{\mathrm{a}}}{\mathrm{b}} \\
& L O Q=\frac{10 \mathrm{~S}_{\mathrm{a}}}{\mathrm{b}}
\end{aligned}
$$

Sa adalah standar deviasi dan b adalah slope.

Perhitungan $L o D$ dan $L O Q$ pada penelitian ini didasarkan pada kurva linear karena hasil standar deviasi analisis blanko bernilai nol. Data perhitungan $L O D$ dan $L O Q$ ditampilkan pada Tabel 2.

Tabel 2. Data pengukuran $L o D$ dan $L o Q$ dengan penentuan kurva linear

\begin{tabular}{ccccc}
\hline$x$ & $y$ & $y_{i}$ & $y-y_{i}$ & $\left(y-y_{i}\right)^{2}$ \\
\hline 0 & 0,0000 & 0,0000 & 0,0000 & 0,0000 \\
2 & 0,1306 & 0,1314 & $-8,06 \times 10^{-4}$ & $6,50 \times 10^{-7}$ \\
4 & 0,2691 & 0,2512 & $1,79 \times 10^{-2}$ & $3,19 \times 10^{-4}$ \\
6 & 0,3696 & 0,371 & $-1,40 \times 10^{-3}$ & $1,95 \times 10^{-6}$ \\
8 & 0,5032 & 0,4908 & $1,24 \times 10^{-2}$ & $1,54 \times 10^{-4}$ \\
10 & 0,5956 & 0,6106 & $-1,50 \times 10^{-2}$ & $2,26 \times 10^{-4}$ \\
\hline
\end{tabular}

Langkah selanjutnya yaitu menentukan nilai $S(y / x)$. Nilai $S(y / x)$ dicari dengan menggunakan persamaan (5):

$$
\mathrm{S}=\sqrt{\frac{\sum\left(\mathrm{y}-\mathrm{y}_{\mathrm{i}}\right)^{2}}{\mathrm{n}-2}}
$$

Nilai $L o D$ dan $L o Q$ dicari dengan persamaan (3) dan (4). Sehingga diperoleh nilai $S(y / x)$ sebesar 0,013257, nilai $L o D$ sebesar $0,663939 \mathrm{mg} / \mathrm{L}$ dan $L o Q=2,213131 \mathrm{mg} / \mathrm{L}$.

\section{Penentuan Presisi}

Presisi adalah ukuran yang menunjukkan kedekatan antara nilai hasil pengukuran dari sampel yang homogen pada kondisi normal atau sampel yang sama diuji secara berurutan dengan menggunakan alat yang sama.
Pada tahap ini penentuan presisi dilakukan dengan mengukur absorbansi sampel pada panjang gelombang optimum sebanyak tujuh kali pengulangan. Data penentuan presisi dapat dilihat pada Tabel 3 . Persen RSD bernilai lebih dari $2 \%$, hal ini menunjukkan bahwa metode uji tersebut memiliki presisi yang tidak baik. Presisi dapat ditentukan berdasarkan CV Horwitz. Persen CV Horwitz dapat dihitung dengan persamaan (6), sedangkan CV pengukuran bernilai sama dengan \% RSD atau dapat dituliskan seperti pada persamaan (7).

$\% C V=2^{1-0,5 \log C}$

$\% \mathrm{CV}_{\text {pengukuran }}=\frac{\mathrm{SD}}{\mathrm{X}} \times 100 \%$ 
Tabel 3. Data penentuan presisi penentuan asetosal menggunakan spektrofotometri UV

\begin{tabular}{cccc}
\hline $\begin{array}{c}\text { Absorbansi } \\
\text { Replikat 1 }\end{array}$ & $\begin{array}{c}\text { Absorbansi } \\
\text { Replikat 2 }\end{array}$ & $\begin{array}{c}\text { Konsentrasi Replikat 1 } \\
(\mathrm{mg} / \mathrm{L})\end{array}$ & $\begin{array}{c}\text { Konsentrasi Replikat 2 } \\
(\mathrm{mg} / \mathrm{L})\end{array}$ \\
\hline 0,2831 & 0,2969 & 4,5326 & 4,7630 \\
0,2829 & 0,2959 & 4,5292 & 4,7462 \\
0,2829 & 0,2968 & 4,5292 & 4,7613 \\
0,3029 & 0,3162 & 4,8631 & 5,0851 \\
0,3028 & 0,3161 & 4,8614 & 5,0835 \\
\hline Rata-rata & 4,6631 & 4,8878 \\
SD & 0,1818 & 0,1795 \\
\% RSD & 3,8990 & 3,6722 \\
$\%$ CV & 12,6903 & 12,6008 \\
\hline
\end{tabular}

Presisi berdasarkan CV Horwitz masih dapat diterima karena \% RSD nilainya lebih kecil dibandingkan dengan nilai \% CV

\section{Penentuan Akurasi}

Akurasi adalah ukuran yang menunjukkan derajat kedekatan hasil analis dengan kadar analit yang sebenarnya. Pada penelitian ini, penentuan akurasi dilakukan dengan melakukan pengukuran absorbansi larutan standar dengan konsentrasi $6 \mathrm{mg} / \mathrm{L}$ sebanyak lima kali pengulangan. Data pengukuran akurasi metode penentuan asetosal dengan metode spektrofotometri UV dapat dilihat pada Tabel 4.

Persen trueness yang diperoleh sebesar 93,88\% menunjukkan bahwa metode analisis yang digunakan memiliki akurasi yang baik. Hal tersebut berdasarkan nilai akurasi pada rentang kesalahan yang diijinkan pada setiap konsentrasi analit dalam matriks $0,001 \%<A \leq 0,1 \%$ yaitu sebesar 90-107\% (Harmita, 2004).

Tabel 4. Data pengukuran akurasi penentuan asetosal dengan metode spektrofotometri UV

\begin{tabular}{ccccc} 
n- & Absorbansi & $\begin{array}{c}\text { Konsentrasi terukur } \\
(\mathrm{mg} / \mathrm{L})\end{array}$ & $\begin{array}{c}\text { Konsentrasi rata-rata } \\
(\mathrm{mg} / \mathrm{L})\end{array}$ & $\begin{array}{c}\% \\
\text { Trueness }\end{array}$ \\
\hline 1 & 0,155 & 5,6327 & & \\
2 & 0,155 & 5,6327 & & \\
3 & 0,155 & 5,6327 & 5,6327 & \\
4 & 0,155 & 5,6327 & & \\
5 & 0,155 & 5,6327 & & \\
6 & 0,155 & 5,6327 & & \\
\hline
\end{tabular}

\section{Penentuan Ketidakpastian Pengukuran}

Ketidakpastian atau uncertainty pengukuran tidak sama dengan kesalahan atau (error). Ketidakpastian pengukuran dapat diminimalkan karena sudah diketahui sebelum dilakukan suatu pengukuran dengan metode analisis tertentu. Hasil pengukuran tidak berarti tanpa adanya perkiraan uncertainty. Pengukuran yang menghasilkan data reliable dan comparable sangat penting dalam pengambilan keputusan terkait spesifikasi produk.

Asetosal merupakan produk obat yang penggunaannya sangat luas, bahkan asetosal menjadi pilihan pertama untuk mengatasi rasa sakit. Ketepatan dosis penggunaan tidak bisa diabaikan, kadar asetosal harus diketahui secara tepat. Oleh karena itu, penting dilakukan perhitungan ketidakpastian pengukuran pada penentuan kadar asetosal dalam sediaan obat seperti dalam obat sakit kepala menggunakan metode spektrofotometri UV sehingga pernyataan hasil akhir pengukuran dinyatakan lengkap.

Penetapan kadar asetotal dengan menggunakan metode spektrofotometri UV yang telah dilakukan memiliki beberapa sumber ketidakpastian antara lain: sampling, spesifikasi instrumen, kemurnian reagen dan zat standar, kesalahan acak (repeatability, reproducibility), personel, preparasi contoh uji, kurva kalibrasi dan homogenitas contoh. Beberapa sumber 
ketidakpastian tersebut dirangkum dalam diagram tulang ikan pada Gambar 3.

Data sumber-sumber ketidakpastian dan konversi ketidakpastian baku dari sumber-sumber tersebut disajikan secara detail pada Tabel 5. Berdasarkan data nilai ketidakpastian baku yang diperoleh, selanjutnya dihitung ketidakpastian gabungan. Ketidakpastian gabungan diperoleh dengan menggabungkan komponenketidakpastian baku dari masingmasing sumber.

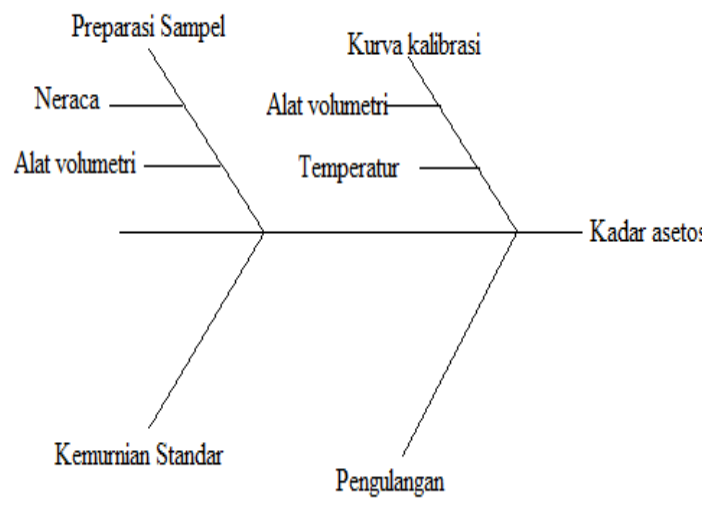

Gambar 3. Diagram tulang ikan
Berdasarkan Tabel 5 dapat dihitung ketidakpastian kombinasi $\left(\mu_{\mathrm{c}}\right)$. Ketidakpastian kombinasi dapat dihitung dengan menggunakan persamaan (8).

$$
\mu_{\mathrm{C}}=\text { kadar asetosal } \mathrm{x} \sqrt{\Sigma\left(\frac{\mu_{\mathrm{x}}}{\mathrm{x}}\right)^{2}}
$$

Ketidakpastian kombinasi yang diperoleh yaitu sebesar $0,158175 \mathrm{mg} / \mathrm{L}$.

Tahap selanjutnya setelah diperoleh $\mu \mathrm{c}$ dilakukan perhitungan ketidakpastian diperluas. Ketidakpastian diperluas merupakan hasil perkalian antara ketidakpastian gabungan $(\mu \mathrm{g})$ dan faktor pencakupan ( $\mathrm{k}$ ), $\mathrm{k}$ bernilai 2 atau tingkat kepercayaan 95\%. Akhirnya diperoleh nilai ketidakpastian diperluas sebesar 0,316349 $\mathrm{g} / \mathrm{mL}$, sehingga dapat dituliskan hasil konsentrasi asetosal dalam larutan sampel yang diukur adalah 4,7755 $\pm 0,316349$ ) $\mathrm{g} / \mathrm{mL}$. Sehingga keseluruhan hasil verifikasi metode analisis penetapan asetosal dengan menggunakan spektrofotometri UV dapat dituliskan seperti pada Tabel 6 . Berdasarkan data Tabel 6 metode spektrofotometri UV yang digunakan untuk menentukan asetosal dalam tablet obat terverifikasi dengan baik.

Tabel 5. Konversi ketidakpastian pengukuran kadar

\begin{tabular}{lccc}
\multicolumn{1}{c}{ Sumber Ketidakpastian } & Nilai $x$ & Nilai $\mu_{x}$ & Nilai $\left(\mu_{x} / \mathrm{x}\right)$ \\
\hline Neraca & $0,025 \mathrm{~g}$ & $2,46 \times 10^{-5} \mathrm{~g}$ & $9,84 \times 10^{-4}$ \\
Kemurnian standar & & & \\
Kalibrasi alat volumetri & $99,91 \%$ & $5,20 \times 10^{-3} \%$ & $5,20 \times 10^{-5}$ \\
Pipet ukur $1 \mathrm{~mL}$ & $1 \mathrm{~mL}$ & $7,51 \times 10^{-4} \mathrm{~mL}$ & $7,51 \times 10^{-4}$ \\
Pipet ukur $5 \mathrm{~mL}$ & $5 \mathrm{~mL}$ & $1,15 \times 10^{-3} \mathrm{~mL}$ & $2,30 \times 10^{-4}$ \\
Labu ukur $10 \mathrm{~mL}$ & $10 \mathrm{~mL}$ & $2,31 \times 10^{-2} \mathrm{~mL}$ & $2,31 \times 10^{-3}$ \\
Labu ukur $50 \mathrm{~mL}$ & $50 \mathrm{~mL}$ & $3,46 \times 10^{-2} \mathrm{~mL}$ & $6,92 \times 10^{-4}$ \\
Labu ukur $100 \mathrm{~mL}$ & $100 \mathrm{~mL}$ & $5,77 \times 10^{-2} \mathrm{~mL}$ & $5,77 \times 10^{-4}$ \\
Labu ukur $250 \mathrm{~mL}$ & $250 \mathrm{~mL}$ & $8,66 \times 10^{-2} \mathrm{~mL}$ & $3,46 \times 10^{-4}$ \\
Faktor Muai (Temperatur) & & & \\
Pipet ukur $1 \mathrm{~mL}$ & $1 \mathrm{~mL}$ & $1,09 \times 10^{-2} \mathrm{~mL}$ & $1,09 \times 10^{-2}$ \\
Pipet ukur $5 \mathrm{~mL}$ & $5 \mathrm{~mL}$ & $5,46 \times 10^{-2} \mathrm{~mL}$ & $1,09 \times 10^{-2}$ \\
Labu ukur $10 \mathrm{~mL}$ & $10 \mathrm{~mL}$ & $1,09 \times 10^{-1} \mathrm{~mL}$ & $1,09 \times 10^{-2}$ \\
Labu ukur $50 \mathrm{~mL}$ & $50 \mathrm{~mL}$ & $5,46 \times 10^{-1} \mathrm{~mL}$ & $1,09 \times 10^{-2}$ \\
Labu ukur $100 \mathrm{~mL}$ & $100 \mathrm{~mL}$ & $1,0900 \mathrm{~mL}$ & $1,09 \times 10^{-2}$ \\
Labu ukur $250 \mathrm{~mL}$ & $250 \mathrm{~mL}$ & $2,7280 \mathrm{~mL}$ & $1,09 \times 10^{-2}$ \\
Pengulangan pengukuran & $4,7755 \mathrm{mg} / \mathrm{L}$ & $9,27 \times 10^{-2} \mathrm{mg} / \mathrm{L}$ & $1,94 \times 10^{-2}$ \\
& & & \\
\hline
\end{tabular}


Tabel 6. Data perbandingan antara kriteria penerimaan dan hasil validasi metode analisis

\begin{tabular}{|c|c|c|c|}
\hline Parameter validasi & Nilai yang diukur & Nilai & Kriteria Penerimaan \\
\hline Linearitas & $R^{2}$ & 0,9967 & $\sqrt{ }$ \\
\hline$L O D$ & LoD & $0,0664 \mathrm{mg} / \mathrm{L}$ & $\sqrt{ }$ \\
\hline$L O Q$ & $L O Q$ & $2,2131 \mathrm{mg} / \mathrm{L}$ & $\sqrt{ }$ \\
\hline Presisi & $\%$ RSD & $3,7856 \%$ & \\
\hline & $\begin{array}{c}\% \text { CV Horwitz } \\
\mu G\end{array}$ & $\begin{array}{c}12,6456 \% \\
\pm 0,3163 \mathrm{~g} / \mathrm{mL}(6,6 \%)\end{array}$ & $\sqrt{ }$ \\
\hline Akurasi & $\%$ Trueness & $93,88 \%$ & $\sqrt{ }$ \\
\hline
\end{tabular}

\section{SIMPULAN}

Kesimpulan yang diperoleh dalam penelitian ini adalah nilai parameter uji validasi yang meliputi linearitas, LoD, LoQ, presisi, akurasi dan estimasi ketidakpastian pengukuran termasuk dalam kategori diterima, dengan nilai secara berurutan adalah 0,$9967 ; 0,0664 \mathrm{mg} / \mathrm{L} ; 2,2131 \mathrm{mg} / \mathrm{L}$, $3,7856 \% ; 93,88 \%$ dan $\pm 0,3163 \mathrm{~g} / \mathrm{mL}$.

\section{SARAN}

Berdasarkan hasil yang diperoleh dalam penelitian, disarankan dalam penentuan asetosal menggunakan spektrofotometri UVdilakukan pegulangan pengukuran secara tepat, karena pengulangan pengukuran ternyata memiliki konstribusi terbesar dalam penyumbang ketidakpastian pengukuran.

\section{UCAPAN TERIMAKASIH}

Ucapan terima kasih penulis tujukan kepada Direktorat Penelitian dan Pengabdian Masyarakat Universitas Islam Indonesia (DPPM UII) yang telah mendanai penelitian ini. Nomor surat kontrak penelitian 266a/ KaPro/ DIII. AK/60/XII/2016.

\section{DAFTAR PUSTAKA}

Bharate, S. S., dan Bharate, S. B. 2012. Spectrophotometric and Chromatographic Determination of Acetylsalicylic Acid and Caffeine in Pure and in Tablet Dosage Form. Journal of Advanced Scientific Research. 3(1), 73-81.

Cemal, A., Ahmet, S., Ahmet, A., dan Yalcin, O. H. G. 2008. Rapid and Simultaneous Determination of
Acetylsalicylic Acid, Parcetamol, and Their Degradation and Toxic Impurity Products by HPLC in Pharmaceutical Dosage Forms. Turkish Journal of Medical Sciences.38(2), 167-173.

Chan, C. C., Lee, Y. C., dan Zhang, X. 2004. Analytical Method Validation and Instrumental Performance Verification. Canada: Willey Intercine A. John Willy and Sons. Inc., Publication.

Gujarathi, S. C. 2010. Simultaneous Determination of Aspirin and Ticlopidine in Combined Tablet Dosage from by First Order Derivative Spectroscopy, Area Under Curve (AUC) and Ratio Derivative Spectrophotometric Methods. International Journal of Pharmaceutical Sciences Review and Research.3(1), 115-119.

Harmita. 2004. PetunjukPelaksanaan Validasi Metode dan Perhitungannya. Majalah IImu Kefarmasian, 1(3), 117135.

Kantasubrata, J. 2008. Validasi Metode. Bandung: Pusat Penelitian LIPI.

Martos, N. R., Diaz, M. A., \& Navalon, A. 2001.

Spectrofluorimetric Determination of Acetylsalicylic Acid and Codeine Mixtures in Pharmaceuticals. Anlytical Letters. 34(4), 579-595.

Martos, N. R., Gomez, A. F., Diaz, M. ., \& Vallvey, C. L. 2001. Application of Liquid Chromatography to the Simultaneous Determination of Acetylsalicylic Acid, Caffeine, Codeine, Paracetamol, Pyridoxine and Thiamine in Pharmaceutical 
Preparations. Journal of AOAC International.84(3), 676-683.

Mishra, P., \& Archana, D. 2006. Simultanious Determination of Clopidogrel and Aspirin in Pharmaceutical Dosage Forms. Indian Journal of Pharmaceutical Sciences.68(3), 365-368.

Murtaza, G., Khan, S. A., Shabbir, A., Mahmood, A., Hasan, M. H., Farzana, K., ... Hussain, I. 2011. Development of a UV-Spectrophotometric Method for The Simultaneous Determination of Aspirin and Paracetamol in Tablets, Scientific Research Essays.6(2), 417421.

Szostak, R., \& Mazurek, S. 2002. Quantitative Determination of Acetylsalicylic Acid and Acetaminophen in Tablets by FTRaman Spectroscopy.Analyst. 127(1), 144-148. 